JOURNAL OF SECURITY AND SUSTAINABILITY ISSUES

ISSN 2029-7017 print/ISSN 2029-7025 online

2020 March Volume 9 Number 3

https://doi.org/10.9770/jssi.2020.9.3(12)

Scopus

\title{
LEGAL SAFETY OF THE REPUBLIC OF POLAND
}

\author{
Marcin Jurgilewicz \\ Rzeszów University of Technology, Aleja Powstańców Warszawy 12, 35-959 Rzeszów, Poland \\ E-mail:m.jurgilewicz@prz.edu.pl
}

Received 15 March 2019; accepted 10 January 2020; published 30 March 2020

\begin{abstract}
Legal security is understood as the protection of vital goods and human interests by means of universally binding normative acts, which should be legible and understandable for their addressees, because the beneficiary of legal security is man. Due to the complexity of this concept, legal security can be considered from different perspectives in both formal and institutional terms, which has also been considered in this article.
\end{abstract}

Keywords: security; law; sources of law

Reference to this paper should be made as follows: Jurgilewicz, M. 2020. Legal safety of the republic of Poland. Journal of Security and Sustainability Issues, 9(3), 869-875. https://doi.org/10.9770/jssi.2020.9.3(12)

JEL Classifications: K14, K15

Additional disciplines: political sciences and administration, law.

\section{Introduction}

The term security has been known to mankind for a long time, although it has changed profoundly for years. Initially, this concept had an individualized character, which could be reduced to the mental state of the individual conditioned by a sense of direct threat in a natural environment unknown to him and the resulting dangers. Over time, this concept began to show inherent links with society, so the resulting normative solutions of a universally binding nature were and are still being directed towards ensuring the optimal safety possible. Nowadays there are distinguished a myriad facets of insecurity (e.g. Moumen et al., 2019; Akhmadeev et al., 2019; Sitdikova, Starodumova 2019; Korauš et al., 2019; Tvaronavičienė, 2018; Lialina, 2019; Prause et al., 2019). Nowadays, legal conditions include complex institutional and legal security systems, which are to be a model of security guarantees for society (Jurgilewicz, Sulowski 2018; Jędrzejowska-Schiffauer \& Schiffauer, 2017).

The universal security context perceived in the individual aspect allows to draw attention to feelings formulated by individuals, which include, apart from objectively perceptible elements, also subjective sensations conditioning the state of safety or danger. An individual, therefore, for the sake of participation in society, as well as the degree of information, will display appropriate attitudes conditioned by the level of security. The behavior of an individual in public space is a derivative of various factors affecting him, which, together with his feelings, including above all a sense of legal certainty, as well as opportunities to meet needs, can be seen in terms of legal security (Misiuk, 2013; Jovovic et al., 2017). 


\section{The importance of legal safety and state safety}

Therefore, when talking about legal security, one should remember about its usefulness for securing vital goods and human interests, which are under their jurisdiction, because the beneficiary of legal security is undoubtedly human. Considering the notion of legal security, it is possible to introduce a model distinction between legal security in formal and institutional terms. The first of these - legal security in formal terms - can be derived from the content of existing legal solutions, i.e. applicable legal acts of various ranks, in particular acts, international agreements or ordinances, which regulate the majority of public and legal areas. Therefore, legal security of an entity in formal terms occurs when the provisions of the law generally applicable in its content regulate a given area of an individual's life. In such a case, it is possible for the entity to effectively enforce the right due to it, which was granted by means of a legal act both in court and pre-trial (e.g. as a result of an agreement between the parties). From this perspective, we can also talk about the legal security of the Republic of Poland, which in formal terms has been successfully reduced to the applicable division of sources of law. According to art. 87 paragraph 1-2 of the Polish Constitution of April 2, 1997, the sources of universally binding law of the Republic of Poland are: the Constitution, statutes, ratified international agreements, ordinances, and acts of local law - in the area of activity of the bodies that established them.

And so the Basic Law is an example of a legal act that stands highest in the hierarchy of the system of sources of law. Its position results not only from its position in the hierarchy of normative acts specified in the catalog of art. 87 paragraph 1 of the Polish Constitution, but also from the content of art. 8 of the Polish Constitution, which states that the Basic Law is the highest law of the Republic of Poland, and its provisions are directly applicable, unless it provides otherwise. In addition, from the so-called of ordinary laws, the Basic Law differs in that it has a special name, content and supreme legal force. It follows that no other legal act may have the same name as the constitution, its content covers all political issues centered around the principles of the state system, organization and structure of public authorities, as well as human and civil liberties and rights, and the subject of its normalization is primary and unlimited.

In addition, the only procedure for amending the Basic Law was specified. According to art. 235 of the Polish Constitution: a bill to amend the Constitution may be submitted by at least $1 / 5$ of the statutory number of deputies, the Senate or the President of the Republic, it shall be amended by means of an act adopted in the same wording by the Sejm and then within no more than 60 days by the Senate.

The first reading of the bill to amend the Constitution may take place no earlier than the thirtieth day after the date of submission of the bill to the Sejm, and the Act on its amendment is adopted by the Sejm by a majority of at least $2 / 3$ of votes in the presence of at least half of the statutory number of deputies and the Senate by an absolute majority of votes in the presence of at least half of the statutory number of senators. In turn, the President of the Republic of Poland signs the act within 21 days of the day of presentation and orders its publication in the Official Gazette of the Republic of Poland. The basic condition for the entry into force of not only the Polish Constitution, but also ordinary laws, international agreements, ordinances and acts of local law is their publication.

As for the laws, it should be noted that their main feature is the implementation of the provisions of the Polish Constitution. The Act can regulate any type of issue if there is no explicit prohibition in this respect in the Basic Law. On the other hand, when it comes to the way bills are drafted, a clear legislative path is foreseen in the Constitution of the Republic of Poland, with no other authority than the parliament authorized to issue a legal act called the act. Another source of universally binding law - international agreements - also form part of the legal order, as they have been indicated in art. 87 paragraph 1 of the Polish Constitution. It should be emphasized that ratification of the international agreement by the Republic of Poland and its termination requires prior consent expressed in the Act, if it concerns:

- peace, alliances, political or military arrangements;

- freedoms, rights or obligations of citizens as set out in the Polish Constitution;

- Poland's membership in an international organization; 
- a significant financial burden on the state;

- matters regulated by statute or in which the Polish Constitution requires a statute.

It should be added that the ratified international agreement, after its publication in the Journal of Laws of the Republic of Poland, forms part of the national legal order and is directly applicable, unless its application depends on the issuance of the act, as well as the fact that if it is a ratified international agreement with prior consent expressed in the act, then it has priority over the act if it cannot be reconciled with the contract. However, according to art. 92 of the Polish Constitution, ordinances are issued by the bodies indicated in the Basic Act, on the basis of a detailed authorization contained in the Act and for the purpose of its implementation. The bodies directly equipped by the Constitution of the Republic of Poland with the power to issue regulations include:

- The President of the Republic of Poland,

- The Council of Ministers,

- Prime Minister,

- ministers managing government administration departments,

- National Broadcasting Council.

The authorization to issue a regulation is always included only in the act, and should also specify the authority competent to do so. In addition, regulations may not violate the norms of the Constitution of the Republic of Poland, the act on the basis of which it was issued, and other binding acts regulating the matters constituting the subject of the regulation. Such violation may consist, for example, in exceeding the scope of statutory delegation, which is expressly prohibited in the Polish Constitution. Among the sources of universally binding law, the legislator also listed acts of local law, while the territorial scope of their validity depends on the area of activity of the authority which establishes them. The legislator did not specify in the Basic Law the names of generic acts of local law, however, by querying normative acts regulating the functioning of individual territorial self-government units in Poland and government administration in the field, it can be indicated that the group of these acts primarily includes:

- resolutions of the resolution bodies of local government units (commune and poviat council or voivodship council) regarding, for example, the budget of the local government unit, local taxes and fees, etc.);

- order regulations adopted by the resolution bodies of local government units or, in urgent cases, by executive bodies in the commune (commune head, mayor or city president) - in the form of an ordinance;

- ordinance ordinances of voivods issued pursuant to the Act on the voivode and government administration in the voivodship;

- acts of local law enacted by unassisted government administration bodies, referred to in the Act on the Voivode and Government Administration in the Province (Haczkowska, 2014).

Sources of law also include internally binding normative acts, to which the law more effectively includes both the resolutions of the Council of Ministers, as well as the ordinances of the Prime Minister and ministers, which, unlike the sources of universally binding law, bind only entities subordinate to the body issuing these acts.

Thus, acts of internal law cannot constitute the basis for decisions regarding citizens, legal persons and other entities, as well as are subject to control as to their compliance with generally applicable law, and their catalog is open, as there may be various types (e.g. regulations, statutes, etc.). In addition, it is worth adding that in addition to the dedicated catalog in Chapter III. The Constitution of the Republic of Poland also refers to sources of universally binding law elsewhere in the Constitution.

According to art. 234 of the Polish Constitution, the President of the Republic of Poland was given the prerogative to issue ordinances with the force of statute, provided that the Sejm cannot meet during a martial law. The President was also given the right to issue a special regulation, i.e. an ordinance on the introduction of martial law or a state of emergency, as determined by Article 231 of the Polish Constitution. The Sejm has the right to 
repeal them by way of a resolution, but what is important, the wording of this norm makes it possible to regard certain resolutions as acts of universally binding law, although, as a rule, resolutions other than acts of local law belong to sources of internal law, so only organizational units subordinate authority issuing these acts, as clearly indicated in the content of art. 93 item 1 of the Polish Constitution.

However, when considering the legal security of the Republic of Poland in institutional terms, the implementation (application) of practice of universally binding law by public authorities and bodies, as well as the issuing of judgments by judicial authorities in accordance with generally applicable law, should be taken into account. In this aspect, we can also talk about the so-called legal certainty, which is fundamental to society. This occurs when the implementation of the content of universally binding law takes place in a socially desirable manner, and the content of normative acts, mainly of statutory status, is legible and understandable for their addressees. The state, acting through authorized bodies belonging to the public authority, is obliged to act as the so-called active legal security entity. It is a matter of the obligation to guarantee the safety of any entity under its jurisdiction. In turn, the entity is a passive legal entity.

At the same time, by pointing to security as a human right, one can see the individual's relationship to the state in which their claim to legal security is emphasized. Thus, the implementation of universally binding law is carried out by authorized entities of public authority, which should include, from the position of the Constitution of the Republic of Poland, organs belonging to the executive branch, i.e. the President of the Republic of Poland and the Council of Ministers (Potrzeszcz, 2015).

Thus, the implementation of universally binding law is carried out by authorized entities of public authority, which should include, from the position of the Constitution of the Republic of Poland, organs belonging to the executive branch, i.e. the President of the Republic of Poland and the Council of Ministers. The President of the Republic of Poland, performing numerous functions and performing various tasks, is obliged to perform provisions arising from the Constitution of the Republic of Poland, which can be cataloged. Then they will refer in particular to: extraordinary legislation and ordinary foreign relations, personal and administrative-organizational rights, as well as the issuing of individual acts. According to art. 126 of the Polish Constitution, the President of the Republic of Poland is the highest representative of the state and a guarantor of the continuity of state power. He has the duty to ensure compliance with the Polish Constitution, guard the sovereignty and security of the state and the inviolability and independence of its territory. The scope of his rights has been determined by both the basic act and the special laws, which means that he has both general competences and powers, which are implemented in situations of special threats and in emergency situations. Among the main powers of the President of the Republic of Poland of a general nature serving the implementation of ongoing tasks in the field of his duties include, among others the right to legislative initiative, the right to sign or refuse to sign a given act, the right to submit an application to the Constitutional Tribunal for a declaration of compliance of a normative act with the Constitution of the Republic of Poland, the right to convene the Cabinet Council in matters of particular importance, as well as the right to issue ordinances and orders. In turn, the President of the Republic of Poland has a broader scope of powers in the event of particular threats to national security, then he has the right to issue a resolution on the state of war if the Sejm cannot gather for a meeting or order to defend the Republic of Poland - at the request of the Prime Minister - universal or partial mobilization and use of the Armed Forces (Jurgilewicz, 2017).

However, in situations of particular threats, when ordinary constitutional measures have already become insufficient, it is possible to introduce a state of emergency on part or all of the state's territory. There are three types of emergency states, i.e. martial law - introduced in the event of an external threat to the state, armed attack on the territory of the Republic of Poland or when an obligation to joint defense against aggression arises from an international agreement, a state of emergency - introduced in the event of a threat to the constitutional system, security of citizens or public order or the state of natural disaster - introduced in order to prevent the effects of natural disasters or technical failures bearing the signs of a natural disaster and to remove them.

The next body of executive power is the Council of Ministers. This is an example of a collective body composed of the Prime Minister and ministers (the Council of Ministers may also include: vice presidents of the Council 
of Ministers and chairmen of committees specified in statutes). General regulations regarding the Council of Ministers are indicated in Chapter VI. The Polish Constitution, however, its organization, mode of work and scope of activity of individual ministers are specified in the Act on the Council of Ministers. And so the Council of Ministers conducts the internal and foreign policy of the Republic of Poland, while its scope of competence includes matters of state policy that have not been reserved to other state organs and local government.

In addition, the Council of Ministers manages the government administration, in turn, in the scope and on the principles set out in the Constitution of the Republic of Poland and other acts, its task is in particular: to ensure the implementation of laws, coordinate and control the work of government administration bodies, protect the interests of the Treasury, adopt the draft state budget, manage the implementation of the state budget and adopt the closure of state accounts and the report on the implementation of the budget, exercise general management in the field of relations with other countries and international organizations, conclude international agreements requiring ratification, and approve and terminate other international agreements, exercise general management in the field of national defense and specify annually the number of citizens appointed to active military service, as well as ensuring external and internal security of the state, as well as public order. The Council of Ministers is authorized to take legislative initiative, and in order to implement laws and on the basis of separate authorizations, it also has the right to issue executive acts (ordinances). In addition, the Council of Ministers also has certain powers in the area of preventing the effects of natural disasters or technical failures that have the characteristics of a natural disaster. It may then introduce the territory of the whole country or part of it of a state of natural disaster. On the other hand, an example of a body included in the Council of Ministers, which was indicated separately in the Constitution of the Republic of Poland, is the Prime Minister. Administratively, he has a dual role because he is the chairman of the collegiate body - the Council of Ministers, as well as an independent, supreme body of state administration, equipped with its own scope of competence. The tasks of the Prime Minister include:

- representing the Council of Ministers and managing its work;

- issuing ordinances;

- ensuring implementation of the policy of the Council of Ministers;

- determining the methods of its implementation, coordination and control of the work of the Council of Ministers;

- supervision of local government within the limits specified by law;

- performing the function of official superior of government administration employees.

In turn, the competences of the Prime Minister, as a single-person supreme body of public administration, cover various areas of public life, e.g. he has the right to issue regulations and ordinances, performs personnel functions by appointing e.g. heads of central offices and voivods, as well as oversees some central government administration bodies. In addition, in the Act on government administration departments, the legislator pointed to central organs (offices) of government administration, which operate in the scope of assigned departments, and supervision over them was granted to individual ministers managing a given administration department, but there are also organs (offices) not included in the scope of departments administrations over which supervision is exercised by the Prime Minister. The difference between supreme and central organs is that the managers of central organs are not part of the RM, although their scope of competence and tasks covers the territory of the whole country. It is also worth mentioning that the implementation, as well as lawmaking, as already mentioned, is also carried out by the bodies of local government units.

Territorial self-government is the basic link in decentralized administration that carries out public tasks not reserved by the Constitution of the Republic of Poland or an act for bodies of other public authorities. The authorities of territorial self-government units (communes, poviats, voivodships) include: self-government community, self-government community bodies, i.e. constitutive and control bodies (commune, poviat and voivodship councils) and executive bodies, i.e. the head of commune, mayor, city president, staroste and marshal voivodships. Speaking of institutional legal security, one should also mention the role of judicial power, which is exercised by the courts and tribunals in the Republic of Poland. The courts and tribunals are an example of a 
separate authority that is independent of other authorities, and their role is to issue judgments on behalf of the Republic of Poland, i.e. adjudication on the basis of universally binding law, which is also a manifestation of the implementation of the law and thus constitutes the implementation of the legal security of the Republic of Poland (Chmaj, 2003).

\section{Summary}

To sum up, the legal security of the Republic of Poland in formal terms can be assessed from the perspective of universally binding sources of law, which have been specified in the Polish Constitution. In the constitution, the legislator established the hierarchical structure of the national legal order, while the rank of individual normative acts, i.e. their place in the system of sources of law, can be generally presented in the order from the highest to the lowest legal force. Therefore, the issues of sources of national law (EU law was deliberately omitted due to the limitation of consideration of sources of law specified in the Constitution of the Republic of Poland) were clearly legible, which is a desirable manifestation of the legislative solution. On the other hand, the legal security of the Republic of Poland in institutional terms, although it has been outlined in general, nevertheless proves that there are a number of authorities at various levels that are obliged to implement the law in practice.

\section{References}

Akhmadeev, R., Redkin, A., Glubokova, N., Bykanova, O., Malakhova, L., Rogov, A. 2019. Agro-industrial cluster: supporting the food security of the developing market economy. Entrepreneurship and Sustainability Issues, 7(2), 1149-1170. http://doi.org/10.9770/ jesi.2019.7.1(25)

Chmaj, M. (red.). 2003. Prawo administracyjne. Część ogólna [The administrative law. General part], Warszawa.

Haczkowska, M. (red.). 2014. Konstytucja Rzeczypospolitej Polskiej. Komentarz [Constitution of the Republic of Poland. Comment], Warszawa.

Jędrzejowska-Schiffauer, I., \& Schiffauer, P. (2017). New constraints on mobility in Europe: Policy response to European crises or constitutional ambiguity? Journal of International Studies, 10(3), 9-23. doi:10.14254/2071-8330.2017/10-3/1

Jovovic, R., Draskovic, M., Delibasic, M., \& Jovovic, M. (2017). The concept of sustainable regional development - institutional aspects, policies and prospects. Journal of International Studies, 10(1), 255-266. doi:10.14254/2071-8330.2017/10-1/18

Jurgilewicz, M. 2017. Rola podmiotów uprawnionych do użycia lub wykorzystania środków przymusu bezpośredniego i broni palnej w ochronie bezpieczeństwa i porzadku publicznego [The role of entities authorized to use or use means of direct coercion and firearms in the protection of public safety and order], Siedlce.

Jurgilewicz, M. Sulowski, S. (red.). 2018. W kręgu nauki o bezpieczeństwie [In the circle of security science] , Warszawa.

Konstytucja Rzeczypospolitej Polskiej z dnia 2 kwietnia 1997 r. [The Constitution of the Republic of Poland of April 2, 1997] (Dz.U. $\mathrm{nr} 78$, poz. 483 ze zm.).

Korauš, A., Gombár, M., Kelemen, P., Polák, J. 2019. Analysis of respondents' opinions and attitudes toward the security of payment systems. Entrepreneurship and Sustainability Issues, 6(4), 1987-2002. http://doi.org/10.9770/jesi.2019.6.4(31)

Lialina, A. 2019. Labor market security in the light of external labor migration: new theoretical findings. Entrepreneurship and Sustainability Issues, 6(3), 1105-1125. http://doi.org/10.9770/jesi.2019.6.3(11)

Misiuk, A. 2013. Instytucjonalny system bezpieczeństwa wewnętrznego [Institutional internal security system],, Warszawa.

Moumen, Z., El Idrissi, N.E.A., Tvaronavičienė, M., Lahrach, A. 2019. Water security and sustainable development. Insights into Regional Development, 1(4), 301-317. https://doi.org/10.9770/ird.2019.1.4(2)

Potrzeszcz, J. Podmiot bierny a podmiot czynny bezpieczeństwa prawnego [Passive entity and active entity of legal security] , „Teka Komisji Prawniczej PAN Oddział Lubelski” 2015, t. VIII.

Prause, G., Tuisk, T., Olaniyi. 2019. Between Sustainability, Social Cohesion and Security. Regional Development in North-Eastern Estonia. Entrepreneurship and Sustainability Issues, 6(3), 1135-1154. http://doi.org/10.9770/jesi.2019.6.3(13) 
Sitdikova, L.B., Starodumova, S.J. 2019. Corporate agreement as a means of providing security in the course of entrepreneurship development. Entrepreneurship and Sustainability Issues, 7(1), 324-335. http://doi.org/10.9770/jesi.2019.7.1(24)

Tvaronavičienè, M. 2018. Towards internationally tuned approach towards critical infrastructure protection. Journal of Security and Sustainability Issues, 8(2), 143-150. https://doi.org/10.9770/jssi.2018.8.2(2)

Marcin JURGILEWICZ is the Professor at Rzeszów University of Technologym, PL. Dean of the faculty of management. Head of the Department of Safety Sciences. Research interests: Research interests: internal security, law, mediation.

ORCID ID: orcid.org/0000-0003-2243-2165.

This work is licensed under the Creative Commons Attribution International License (CC BY). http://creativecommons.org/licenses/by/4.0/ 